\title{
Effect of salt and pH on the biomass and phosphatase activity of Burkholderia sp.
}

\author{
F. Lalsangpuii, Lalrampani Chawngthu, R. Lalfakzuala* \\ Laboratory of Microbiology, Department of Botany, Mizoram University, Tanhril 796004, Mizoram, India \\ Corresponding author: lalfaka@yahoo.com
}

\begin{abstract}
Salinity and pH stress have effect on bacterial growth, enzyme activity and cell biomass. Optimum salt concentration and $\mathrm{pH}$ were need for the normal growth of bacteria except for halophiles, acidophiles and alkaliphiles. Different concentration of salt $(2.5,5,10$ and $20 \%)$ and $\mathrm{pH}(5,7,9$ and 11$)$ were introduced on phosphate-solubilizing bacterial (Burkholderia sp.) culture. The result showed that with the increase in the salt concentration there was a decrease in bacterial colony size, biomass and phosphatase activity. The lowest colonial growth and phosphatase activity were observed at $20 \%$ salt concentration. It was also found that at low pH and high pH treatments, a significant drop on bacterial cell biomass and phosphatase activity were observed. pH7 showed the best bacterial colony size and phosphatase activity.
\end{abstract}

Keywords: Phosphatase activity, salinity, pH, phosphate-solubilizing bacteria, Burkholderia sp.

\section{INTRODUCTION}

Phosphorus plays a significant role in several physiological and biochemical plant activities like photosynthesis, transformation of sugar to starch, transporting of the genetic traits. Soil microorganisms play a key role in soil phosphorus dynamics and subsequent availability of phosphate to plants (Richardson, 2007). Phosphatesolubilizing bacteria (PSB) are known to improve plant growth and health, enhance hormonal level and produce various secondary metabolites detrimental to plant pathogen (Dey et al., 2004).

The population, growth, survival activities and $\mathrm{P}$ solubilization efficiency of PSB are greatly influenced by soil physical, chemical and biological stresses. Stress can be detrimental for sensitive microorganisms and decrease the activity of surviving cells, due to the metabolic load imposed by the need for stress tolerance mechanisms (Schimel et al., 2007; Yuan et al., 2007, Ibekwe et al., 2010; Chowdhury, 2011).

In a dry hot climate, the low humidity and soil salinity are the most stressful factors for the soil microbial flora. The composition of the microbial community may be affected by salinity (Pankhurst et al., 2001; Gros et al., 2003; Gennari et al., 2007; Llamas et al., 2008; Chowdhury et al., 2011) since the microbial genotypes differ in their tolerance of a low osmotic potential (Mandeel, 2006; Llamas et al., 2008). In phosphate-solubilizing bacteria, a low osmotic potential decreases spore germination and the growth of hyphae and changes the morphology (Juniper and Abbott, 2006) and gene expression (Liang et al., 2007), resulting in the formation of spores with thick walls (Mandeel, 2006).

There is a significant reduction in the total bacterial count in soils salinized with different concentrations of sodium chloride. Soil $\mathrm{pH}$ affects the chemical form, concentration and availability of substrates (Kemmitt et al., 2006) and influence cell growth and activity. There is also strong evidence that soil $\mathrm{pH}$ is an important determinant of bacterial diversity and community structure on a global scale (Fierer and Jackson, 2006).

Rates of nitrification is significantly reduced in acid soils (de Boer and Kowalchuk, 2001), and significant batch growth of pure cultures of bacteria in liquid growth media does not occur below pH 7 (de Boer and Laanbroek, 1989; Allison and Prosser, 1991; Jiang and Bakken, 1999). pH strongly influences abiotic factors, such as carbon availability, nutrient availability, and the solubility of metals. In addition, $\mathrm{pH}$ may also control biotic factors, such as the biomass composition of bacteria and their enzyme activity. 


\section{MATERIALS AND METHODS}

\section{Test organism}

Burkholderia sp., phosphorus-solubilizing bacteria, was selected for the test organism. Stock culture was prepared in $250 \mathrm{ml}$ conical flask containing $50 \mathrm{ml}$ of nutrient broth (Difco Manual, 1953).

\section{Measurement of bacterial colony diameter}

Nutrient agar medium (Sunder Rao \& Sinha, 1963) was prepared with different concentration of salt $(2.5,5,10$ and $20 \%)$ and $\mathrm{pH}(5,7,9$ and 11). On solidification, a hole was made using corkborer and then Burkholderia sp. from stock culture was transferred to each hole. After $48 \mathrm{hrs}$ of incubation the colony diameter of PSB was measured.

\section{Measurement of bacterial biomass}

Pikovskaya's broth medium (Sunder Rao and Sinha, 1963) was used to culture Burkholderia sp. Pikovskaya's medium without any treatment was used as control ( $\mathrm{pH} \mathrm{6.37)} \mathrm{for} \mathrm{the} \mathrm{study.} \mathrm{The} \mathrm{test} \mathrm{cultures} \mathrm{were}$ divided into triplicates each containing $50 \mathrm{ml}$ of the medium broth treated with different concentration of salt $(2.5,5,10$ and $20 \%)$ and $\mathrm{pH}(5,7,9$ and 11) values. To each flask, $1 \mathrm{ml}$ of bacteria from the stock culture was added. After 48 hours of incubation, the inoculated flasks were filtered with Whatman filter paper No. I. The whole portion of the residue (filter paper) were dried and weighed and the filtrate was used for measuring the bacterial phosphatase activity.

\section{Measurement of phosphatase activity}

Phosphatase activity of Burkholderia sp. was assayed spectrophotometrically by $\mathrm{p}$-nitrophenyl phos- phate (PNP) method (Tabatabai and Bremner, 1969). To $3 \mathrm{ml}$ of aliquot (48 hrs of PSB broth culture medium) $1 \mathrm{ml}$ of modified universal buffer and $1 \mathrm{ml}$ of $0.115 \mathrm{M}$ of PNP were added in $50 \mathrm{ml}$ volumetric flak and was incubated 1 hrs at $37^{\circ} \mathrm{C}$. The reaction was stopped by adding $20 \mathrm{ml}$ of $0.5 \mathrm{~N} \mathrm{NaOH}$ and the volume was made up to $50 \mathrm{ml}$ with $\mathrm{dH}_{2} \mathrm{O}$. The absorbance was taken with a spectrophotometer at $430 \mathrm{~nm}$.

\section{RESULTS}

\section{Colony diameter of PSB}

In salt treatment, control plate showed maximum colony diameter followed by 2.5, 5, 10 and 20 concentration of salt (Figure 1) has the smallest colony diameter. In $\mathrm{pH}$, control plate showed maximum growth followed by $\mathrm{pH} \mathrm{7,} \mathrm{5,} 9$ and $\mathrm{pH} 11$ has the smallest diameter (Figure 2). ANOVA showed that there was significant variation in colony diameter of Burkholderia sp. among different treatments (Table 1).

\section{Biomass of PSB}

Biomass of Burkholderia sp. was measured from different treatment of salt, viz. 2.5\%, 5\%,10\% and $20 \%$ and $\mathrm{pH}$ viz. 5, 7, 9 and 11 and control was maintained. It was noted that Control showed maximum biomass. In salt treatment, 2.5 show the maximum biomass followed by 5,10 and 20 . There is maximum growth in $\mathrm{pH} 7$ followed by $\mathrm{pH} 5, \mathrm{pH} 9$ and $\mathrm{pH} 11$. ANOVA showed that there was significant variation in biomass of Burkholderia sp. among different treatments (Table 2).

\section{Phosphatase Enzyme Activity}

Phosphatase activity was measured from Burkholderia sp. treated with different salt and $\mathrm{pH}$. It was noted that control show highest phosphatase activity

Table 1: One-way analysis of variance (ANOVA) of colony diameter of Burkholderia sp. in different concentration of salt and $\mathrm{pH}\left({ }^{*}\right.$ significant at $\left.\mathrm{p} \leq 0.05\right)$.

\begin{tabular}{||l||l||c||c||}
\hline \hline Treatments & \multicolumn{1}{|c||}{ Sources of Variation } & F-value & P-value \\
\hline \hline Salt & CTRL $\times 2.5 \times 5 \times 10 \times 20$ & $134.3984^{*}$ & $0.000000^{*}$ \\
\hline \hline $\mathrm{pH}$ & CTRL $\times 5 \times 7 \times 9 \times 11$ & $75.1556^{*}$ & $0.000000^{*}$ \\
\hline
\end{tabular}

Table 2: One-way analysis of variance (ANOVA) of biomass of Burkholderia sp. in CTRL, 2.5\%, 5\%, 10\% and 20\% of salt and $\mathrm{pH}$ (*significant at $\mathrm{p} \leq 0.05)$.

\begin{tabular}{|l||l||c||c||}
\hline Treatment & Source of variation & F-value & P-value \\
\hline \hline Salt & CTRL $\times 2.5 \times 5 \times 10 \times 20$ & $114.3230^{*}$ & $.000000^{*}$ \\
\hline \hline $\mathrm{pH}$ & CTRL $\times 5 \times 7 \times 9 \times 11$ & $159.0124^{*}$ & $.000000^{*}$ \\
\hline \hline
\end{tabular}


Figure 1: Bacteria colony diameter treated with salt after 48 hours incubation.

Figure 2: Bacterial colony diameter treated with different $\mathrm{pH}$ after 48 hours incubation.

Figure 3: Biomass of Burkholderia sp. treated with different concentration of salt after 48 hours incubation.

Figure 4: Biomass of Burkholderia sp. treated with different concentration of $\mathrm{pH}$ after 48 hours incubation.

Figure 5: Phosphatase activity of Burkholderia sp. treated with different concentration of salt after 48 hours incubation.
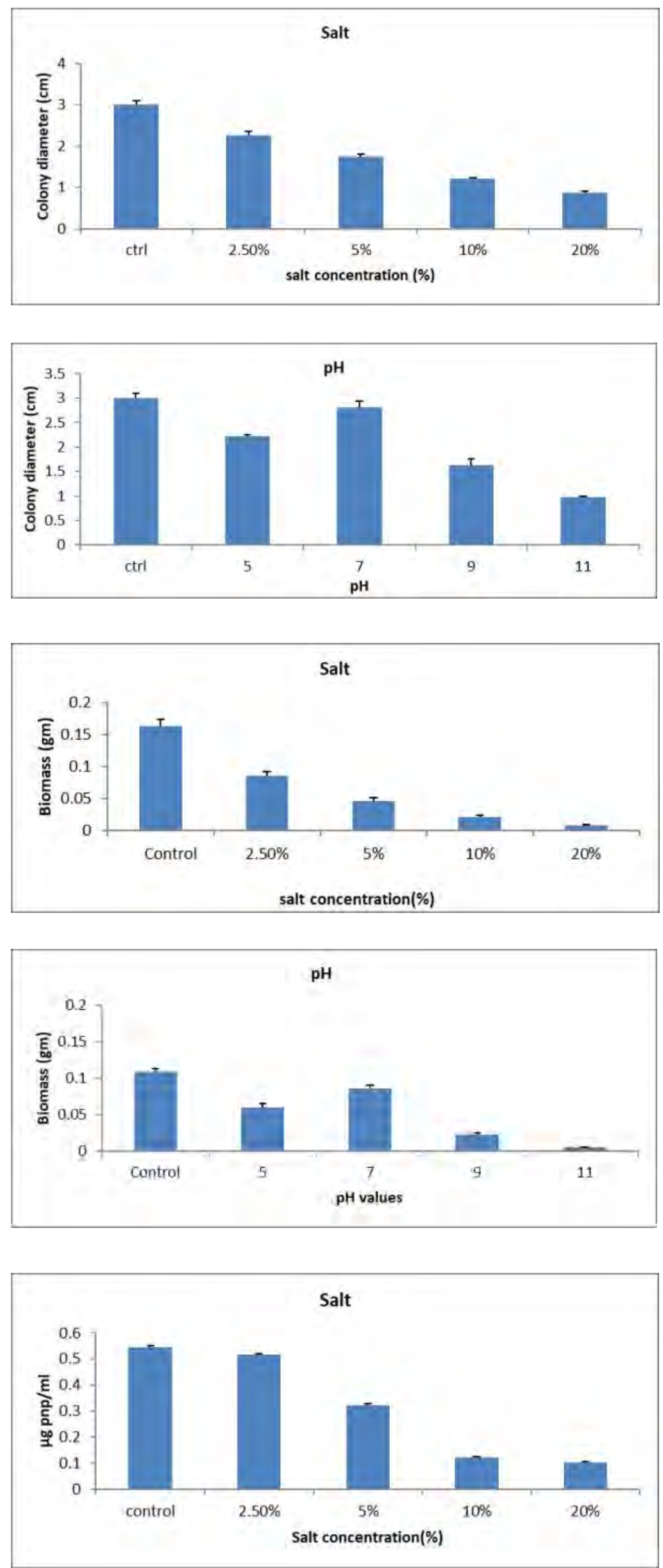
Figure 6: Phosphatase activity of Burkholderia sp. treated with different $\mathrm{pH}$ values after 48 hours incubation.

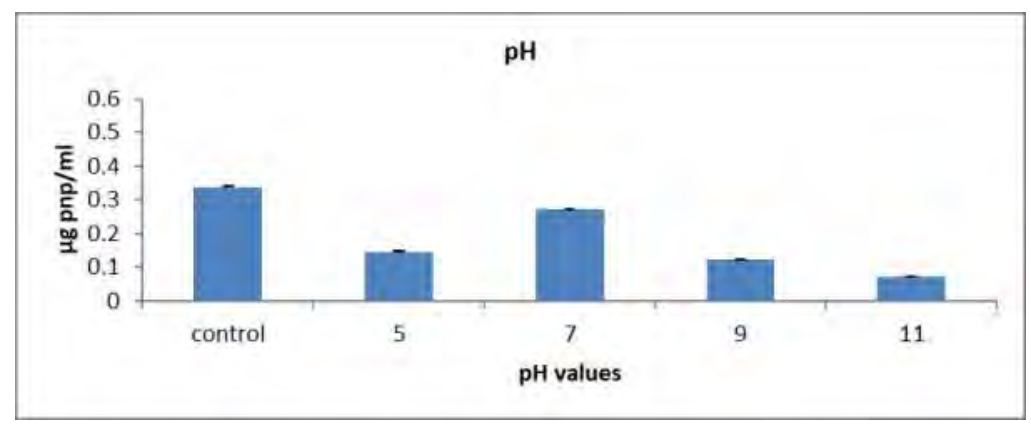

followed by $2.5,5,10$ and $20 \%$ in case of salt treatment. In $\mathrm{pH}$, control is followed by $\mathrm{pH} \mathrm{5,7,9}$ and 11. ANOVA showed that there was significant variation in phosphatase activity of Burkholderia sp. among different treatments (Table 3).

\section{DISCUSSION}

Environment stresses like decrease and increase in salinity and $\mathrm{pH}$ greatly affect the physiological activity of bacteria like in their growth rate, enzymatic activity and even in their biomass. In Burkholderia, the increase in salt concentration, i.e. $2.5,5,10$ and $20 \%$ result in decrease in the colony diameter of bacteria. (Pankhurst et al., 2001; Gros et al., 2003; Gennari et al., 2007; Llamas et al., 2008; Chowdhury et al., 2011). Growth of bacteria was still observed and there was only slight different in the biomass and phosphatase activity with least concentration of salt, i.e. $2.5 \%$. In 20 and $10 \%$ only very small clear zone can be seen and the phosphatase activity declined which was in agreement with the finding of Samiran et al. (2010). Vogel et al. (2010) state that osmotic stress brings forth by high salinity manipulates the growth of all living cells either disrupting the normal physiological activities or intracellular macromolecular structures.

The optimum $\mathrm{pH}$ for the growth of bacteria was about $\mathrm{pH} 6.37$, i.e. the $\mathrm{pH}$ of the medium where the bacterium was cultured. The medium having $\mathrm{pH} 7$ has shown best growth rate and the phosphatase activity was also high as compared other $\mathrm{pH}$ values. This was followed by $\mathrm{pH} 5, \mathrm{pH} 9$ and $\mathrm{pH} 11$, it can be concluded that no growth occurs (Ahlgren and Ahlgren, 1960).

Our experimental result shows that with the increase in salt concentration and $\mathrm{pH}$ values, there was decline in phosphatase enzyme activity and bacterial biomass. Our findings can determine the optimum concentration of the salt and $\mathrm{pH}$ value at which the bacteria will show maximum growth and enzymatic activity. This result also explores the stress tolerance level of the bacteria against $\mathrm{pH}$ and salt concentration.

\section{REFERENCES}

Ahlgren, I.F., Ahlgren, C.E. (1960). Ecological effects of forest fires. Botanical Review 26: 483-533.

Banerjee, S., Palit, R., Sengupta, C., \& Standing, D. (2010). Stress induced phosphate solubilization by Arthrobacter Sp. and Bacillus sp. isolated from tomato rhizosphere. Australian Journal of Crop Science, 4: 378 -383 .

Beales, N. (2004). Adaptation of microorganisms to cold temperatures, weak acid preservatives, low $\mathrm{pH}$, and osmotic stress: a review. Comprehensive Reviews in Food Science and Food Safety, 3: 1-20.

Bunemann, E.K., Bossio, D.A., Smithson, P.C., Frossard, E., Oberson, A. (2004). Microbial community composition and substrate use in a highly weathered soil as affected by crop rotation and P fertilization. Soil Biol. Biochem, 36: 889-901.

Cabello, M., Irrazabal, G., Bucsinszky, A. M., Saparrat M., Schalamuck, S. (2005). Effect of an arbuscular mycorrhizal fungus, G. mosseae and a rock-phosphatesolubilizing fungus, $\mathrm{P}$. thomii in Mentha piperita growth in a soilless medium. J. Basic Microbiol. 45: 182-189.

Chowdhury, N., Marschner, P., Burns, R.G. (2011). Soil microbial activity and community composition: impact of changes in matric and osmotic potential. Soil Biology and Biochemistry, 43: 1229-1236.

Clouse, S.D., Sasse, J.M. (1998). Brassinosteroids: Essential regulators of plant growth and development. Ann Rev. Plant Physiol. M ol. Biol., 49: 427-451.

de Boer, W., Kowalchuk, G.A. (2001). Nitrification in acid soils: micro-organisms and mechanisms. Soil Biol Biochem 33: 853-866.

de Boer, W., Laanbroek, H.J. (1989). Ureolytic nitrification at low $\mathrm{pH}$ by Nitrosospira spec. Arch Microbiol 152: $178-181$

Delvasto, P., Valverde, A., Igual, J.M., Munoz, J.A., Gonzalez, F., Blazquez M.L., Garcia-Balboa, C. (2006). Diversity and activity of phosphate bioleaching bacteria from a high phosphorous iron-ore. Soil Biology and Biochemistry 38: 2645-2654.

Dey, R., Pal, K.K., Bhatt, D.M., Chauhan, S.M. (2004). Growth promotion and yield enhancement of peanut (Arachis hypogaea L.) by application of plant growthpromoting rhizobacteria. Microbial. Res., 159: 371394.

Fierer, N., Jackson, R.B. (2006). The diversity and bio- 

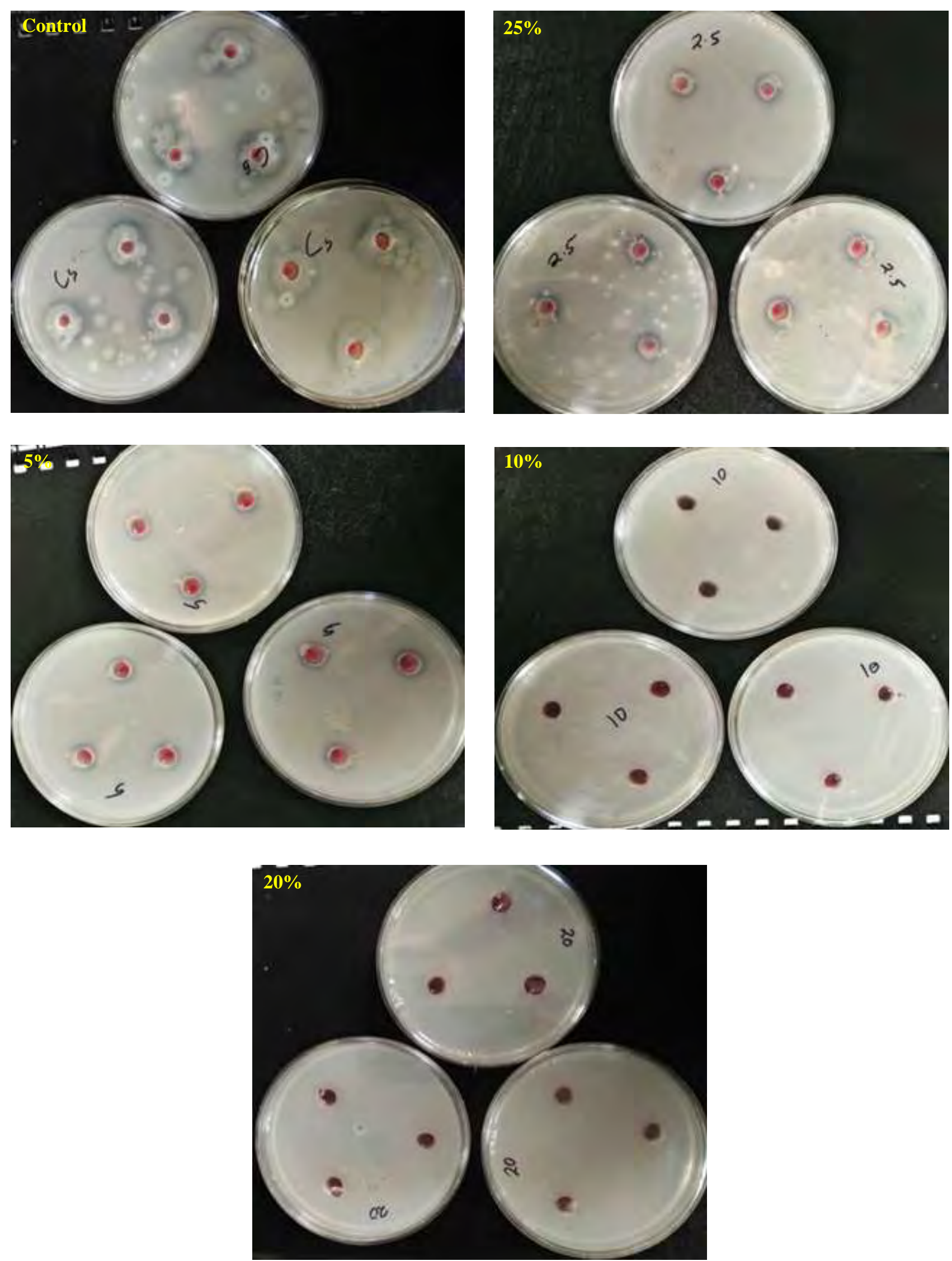

Figure 7: Burkholderia sp. grown on nutrient medium treated with different salt concentration. 


\section{ATLANTIS
PRESS}
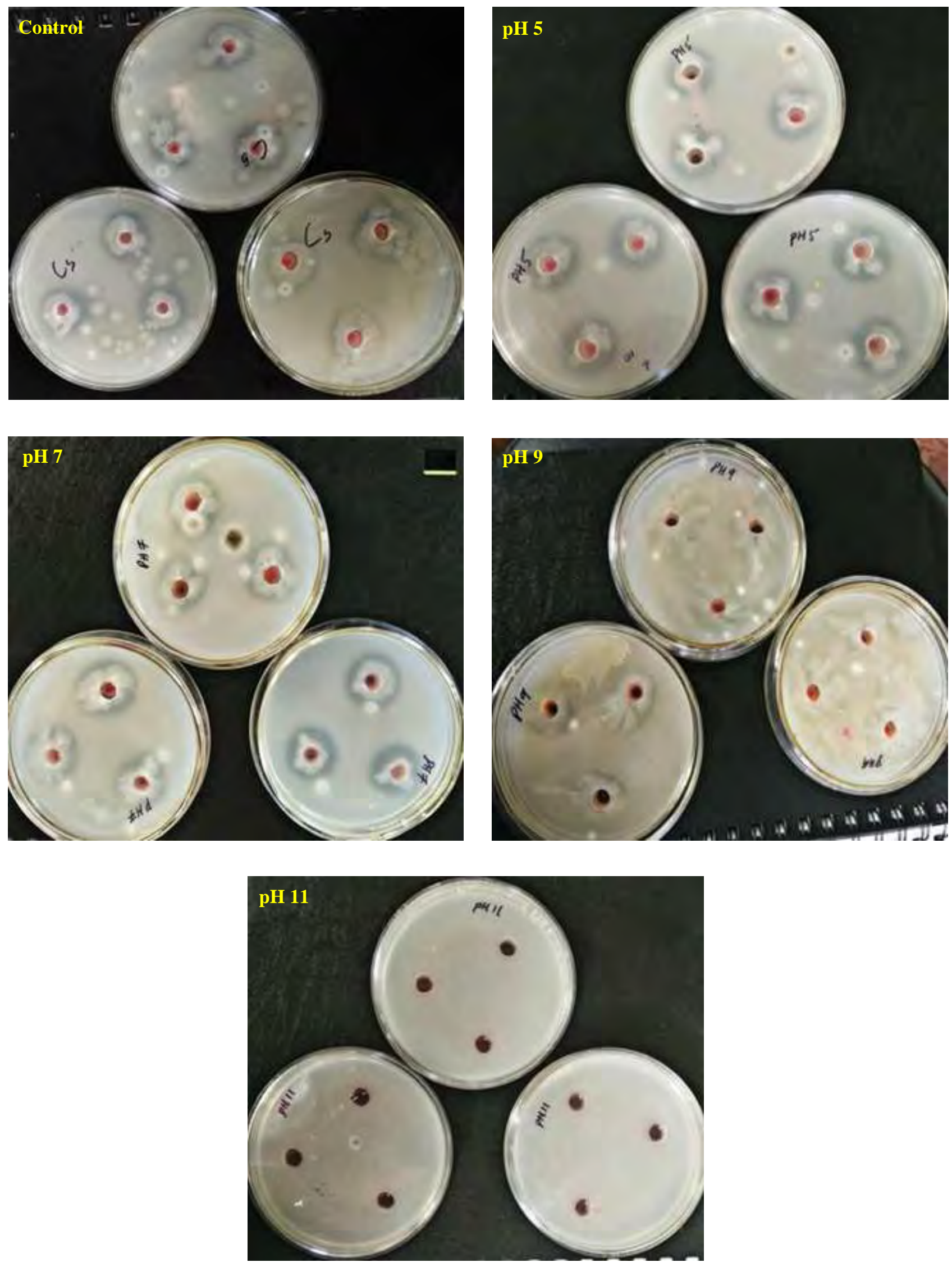

Figure 8: Burkholderia sp. grown on different $\mathrm{pH}$ nutrient medium. 
geography of soil bacterial communities. Proc Nat Acad Sci USA 103: 626-631.

Gennari, M., Abbate, C., La Porta, V., Baglieri, A. \& Cignetti, A. (2007). Microbial response to Na2SO4 additions in a volcanic soil. Arid Land Research and M anagement, 21, 211-227.

Gros, R., Poly, F., Jocteur-Monrozier, L., Faivre, P. (2003). Plant and soil microbial community responses to solid waste leachates diffusion on grassland. Plant and Soil, 255, 445-455.

Ibekwe, A.M., Poss, J.A., Grattan, S.R., Grieve, C.M., Suarez, D. (2010). Bacterial diversity in cucumber (Cucumis sativus) rhizosphere in response to salinity, soil $\mathrm{pH}$, and boron. Soil Biology \& Biochemistry, 42, 567-575.

Jones, A., Ataog, N., Turan, M., Esitken, A., Quirine, M. (2009). Effects of phosphate-solubilizing microorganisms on strawberry yield and nutrient concentrations. J. Plant Nutrition and Soil Sci., 172: 385-392.

Juniper, S., Abbott, L. K. (2006). Soil salinity delays germination and limits growth of hyphae from propagules of arbuscular mycorrhizal fungi. M ycorrhiza, 16: 371379.

Kemmitt, S.J., Wright, D., Goulding, K.W.T., Jones, D.L. (2006). pH regulation of carbon and nitrogen dynamics in two agricultural soils. Soil Biol Biochem 38: 898911.

Khan M. S., Zaidi A., Wani P. A. (2007). Role of phosphate -solubilizing microorganisms in sustainable agriculture - A review. Agronomy for Sustainable Development 27: 29-43.

Liang, J., Wu, W. L., Liu, Z. H., Mei, Y. J., Cai, R. X., Shen, P. (2007). Study the oxidative injury of yeast cells by NADH autofluorescence. Spectrochimica Acta Part A: Molecular and Biomolecular Spectroscopy, 67: 355359.

Llamas, D.P., Gonzales, M.D., Gonzales, C.I., Lopez, G.R., Marquina, J.C. (2008). Effects of water potential on spore germination and viability of Fusarium species. Journal of Industrial Microbiology \& Biotechnology, 35: 1411-1418.

Mandeel, Q.A. (2006). Biodiversity of the genus Fusarium in saline soil habitats. Journal of Basic Microbiology, 46, 480-494.

Nautiyal C.S., Bhadauria S., Kumar P., Lal H., Mondal R., Verma D. (2000). Stress induced phosphate solubiliza- tion in bacteria isolated from alkaline soil. FEMS M icrobiology Letters, 182: 291-296.

Oren, A. (1999). Bioenergetic aspects of halophilism. Microbiology and Molecular Biology Reviews, 63, 334348.

Pankhurst, C.E., Yu, S., Hawke, B.G., Harch, B.D. (2001). Capacity of fatty acid profiles and substrate utilization patters to describe differences in soil microbial communities associated with increased salinity or alkalinity at three locations in South Australia. Biology and Fertility of Soils, 33: 204-217.

Richardson, A. E. (2007). Making microorganisms mobilize soil phosphorus. In: E. Velázquez and C. Rodríguez -Barrueco (eds.) First International M eeting on Microbial Phosphate Solubilization, pp. 85-90.

Sardinha, M.; Muller, T.; Schmeisky, H., Joergensen, R.G. (2003). Microbial performance in soils along a salinity gradient under acidic conditions. Applied Soil Ecology, 23: 237-244.

Schimel, J.P.; Balser, T.C., Wallenstein, M. (2007). Microbial stress response physiology and its implications for ecosystem function. Ecology, 88: 1386-1394.

Sundara, S., Chaichi, M. R., Alikhani, H. A. (2008). Effects of phosphate solubilizing microorganisms and phosphorus chemical fertilizer on yield and yield components of Barley (Hordeum vulgare L.). Am-Euras. J. Agric. \& Environ. Sci. 3: 822-828.

Tabatabai. M.A., Bremner, J.M. (1969). Use of pnitrophenylphosphate for assay of soil phosphatase activity. Soil Biol Biochem 1: 301-307.

Vikram, A., Hamzehzarghani, H., Alagawadi, A.R. (2008). Production of plant growth promoting substances by phosphate solubilizing bacteria isolated from vertisols. J plant Sci., 2: 326-333.

Vogel, J.P., Garvin, D.F., Mockler, T.C, Schmutz, Rokshar, D., Bevan, M.W (2010). Genome sequencing and analysis of the model grass Brachypodium distachyon. Nature, 463 763-768.

Yazdani M., Bahmanyar, M. A., Pirdashti, H., Es-maili, M. A. (2009). Effect of phosphate solubilization microorganisms (PSM) and plant growth promoting rhizobacteria (PGPR) on yield and yield components of corn (Zea mays L.). Proc. World Acad. Science, Eng. Technol. 37: 90-92.

Yuan, B-C; Li, Z-Z; Liu, H; Gao, M., Zhang, Y-Y. (2007). Microbial biomass and activity in salt affected soils under arid conditions. Applied Soil Ecology, 35: 319-328. 